\title{
Chapter 23 \\ New Sago Palm Starch Resources and Starch Pith Waste Properties
}

\author{
Takashi Mishima
}

\begin{abstract}
Generally, Metroxylon sagu Rottb. contains about $400 \mathrm{~kg}$ of dried starch in the pith of each tree. The starch stored in the pith exceeds $300 \mathrm{~kg}$ according to Ehara et al. (Environmental factors limiting sago production and genetic variation in Metroxylon sagu Rottb. In: Karafir YP, Jong FS, Fere VF (eds) Sago palm development and utilization: proceedings of the 8th international sago symposium. Universitas Negri Papua Press, Manokwari, pp 93-103, 2005). However, only 50\% of starch from the deposits can be extracted using current methods, and one-half remains behind in the residue. In this chapter, the characteristics of sago pith residue and features of these unused resources are described. Specific utilization of starch residue by establishing a conversion method as a sweetener is proposed. The food security of sugar from sugarcane may be helped by a sweetener made from sago starch. The genus Metroxylon has two sections. One is Metroxylon and the other one is Coelococcus. Section Coelococcus is a relict crop. The starch content and physicochemical properties of section Coelococcus are presented. It is anticipated that section Coelococcus will be available as a future source of biomass.
\end{abstract}

The cellulose contained within sago palm trunks is a major carbohydrate resource. However, because of its crystallinity, which makes it very difficult to digest, it presents a challenge to process and use in other products. In contrast, sago starch is an important bioresource and can be eaten, is used as feed for animals and microorganisms, and has industrial applications.

Generally, Metroxylon sagu Rottb. contains approximately $400 \mathrm{~kg}$ of dried starch in the pith of a single tree. According to Ehara et al. (2005), more than $300 \mathrm{~kg}$ of starch is stored in the pith. However, only $50 \%$ of the starch from the deposits can be extracted with current methods, and the other half remains in the residual pith waste.

Starch in sago pith waste occurs in the parenchyma cells (Fig. 23.1). Therefore, it is difficult to extract all of the starch from the pith using mechanical processing,

T. Mishima $(\triangle)$

Graduate School of Regional Innovation Studies, Mie University, Tsu, Japan

e-mail: mishima@bio.mie-u.ac.jp 


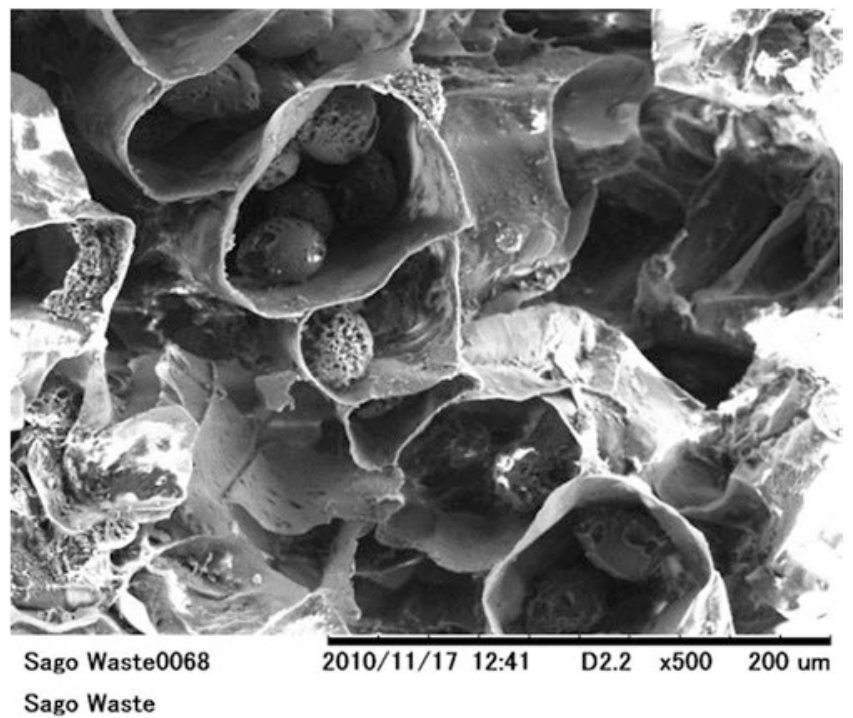

Fig. 23.1 Scanning electron microscope image of sago pith waste Acceleration voltage: $10 \mathrm{kV}$

Note: Holes in the starch may be the result of microorganism digestion

such as a rasper. In this chapter, we propose specific utilization of the starch residue by establishing a conversion method to make it into a sweetener. We also hope that the food security of cane sugar may be improved by producing a sweetener made from sago starch derived from pith waste.

\subsection{Starch in Sago Pith Waste}

The sago palm has a large trunk and grows more quickly than many woody plants. The palm requires approximately 12 years to reach maturity when it is harvestable (Jong 1995). Sago palm has the potential to become an important carbohydrate provider.

From the perspective of industrial starch production, sago palm pith contains approximately $26 \%$ (dry weight) in pith waste (Fig. 23.2). When we measured the starch content using a rasper and also comparatively determined the true starch content using chemical extraction, the pith content was found to be 37 and $77 \%$ in dry weight, respectively (Fig. 23.3). This result confirms that approximately onehalf the volume of starch is left in the pith waste. If we can develop a new extraction technique, it will be possible to use sago pith waste as a biorefinery raw material. 


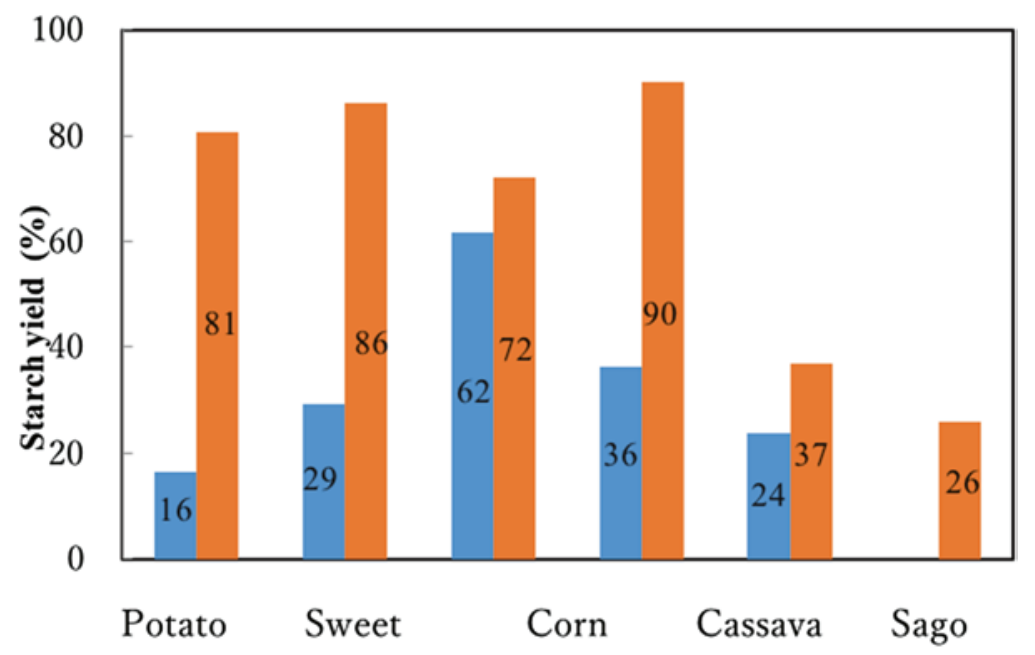

Fig. 23.2 Starch yield of each crop

: Dry starch wet weight

: Dry starch dry weight

Considering the actual processing, the sago palm, like grains, has less water content as compared to the potato

Source: Agriculture and Livestock Industries Corporation 2004, 2008; Jong 1995; Ministry of Agriculture, Forestry and Fisheries, Japan 2009

\subsection{Pith Waste Starch as a Possible Biorefinery Material}

Native starch has a strong crystalline structure that allows it to be stored for a long time. When sago starch is used in the food industry, it is usually treated with water and heat. The process of melting the crystalline structure to make starch is called gelatinization. Gelatinization is an important treatment. Liquefaction and saccharification are important treatments as well. Starch is a glucose polymer with $\alpha-1,4-$ and $\alpha-1,6$-glycosidic bonds. After gelatinization, starch can be easily hydrolyzed by enzymes or acid. The products after liquefaction consist of glucose and maltooligosaccharides. Saccharification makes glucose from liquefaction products. Glucose is an important raw material for sweeteners, ethanols, polyols, organic acids, and amino acids (Whistler 2009).

Simple mechanical treatment of sago pith is an easy and low-cost method. However, the starch yield is quite low. Santoso et al. (2015) proposed a high-level milling treatment for sago pith waste to effectively recover the starch. Please see Chap. 19. This method allows recovery of additional starch from sago pith waste.

As a different method of recovering starch from sago pith waste, a direct liquefaction and saccharification method for sago pith waste is proposed. This method is useful for obtaining maltooligosaccharides and glucose from sago pith waste; 


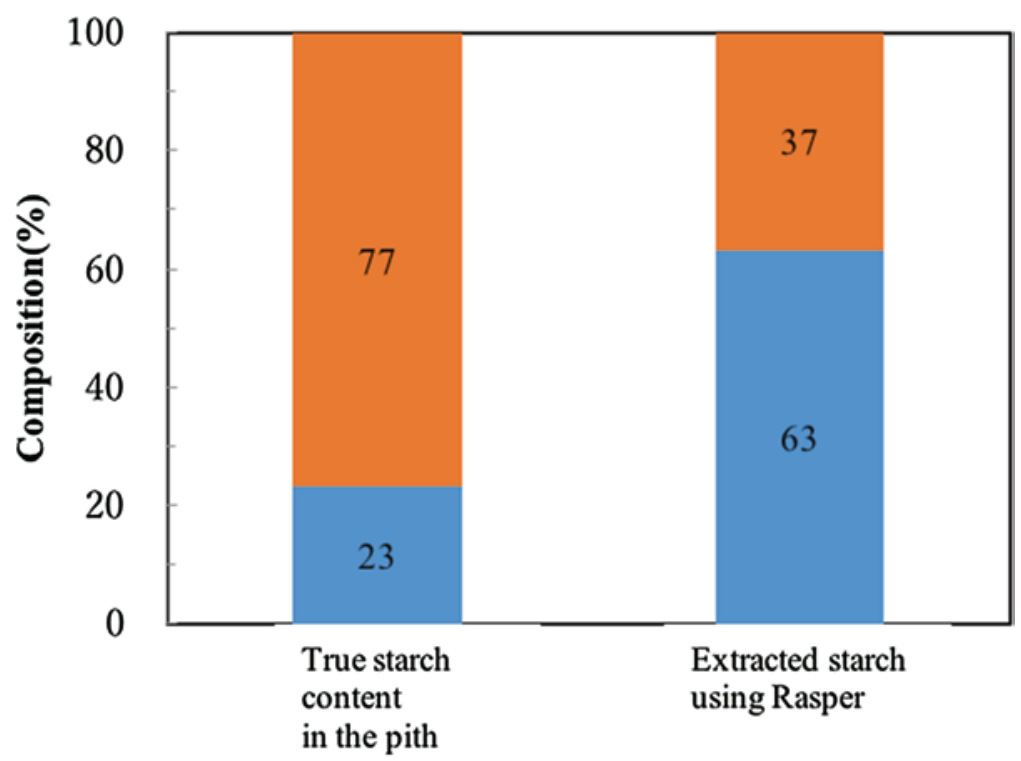

Fig. 23.3 Sago pith and the composition of the extracted substances

: Extracted starch

Others

The starch content was measured and calculated by the solvent extraction method using perchloric acid extraction in order to measure the true starch content

Table 23.1 Viscosity properties of major starch sources

\begin{tabular}{l|l|l|r|r|r|l}
\hline \multirow{2}{*}{ Sample } & \multirow{5}{*}{ Viscosity $($ RVU $)$} \\
\cline { 3 - 7 } & P.T. $\left({ }^{\circ}\right.$ C) & P.V. & F.V. & M.V. & B.D. & S.B. \\
\hline Corn & 76.1 & 114 & 78 & 41 & 72 & 36 \\
\hline Wheat & 84.4 & 108 & 125 & 55 & 54 & 70 \\
\hline Sago & 75.6 & 263 & 192 & 112 & 151 & 80 \\
\hline Potato & 68.9 & 636 & 273 & 204 & 432 & 69 \\
\hline
\end{tabular}

Viscosity measured by Rapid Visco Analyzer RVA-3D (FOSS)

The concentration of the sample was $6 \%$

$P . T$, peak viscosity temperature; $P . V$., peak viscosity; F.V., final viscosity; M.V., minimum viscosity; B.D., breakdown (P.V.-M.V); S.B., setback (F.V.-M.V.)

Source: Kako (2004)

however, some problems must be resolved. Generally, cornstarch is used to make high-fructose corn syrup consisting of fructose and glucose.

The gelatinization process requires agitation, and viscosity is one effective parameter for it. Table 23.1 shows the viscosity of major starch sources. Cornstarch shows the lowest viscosity, and sago starch shows a viscosity twice that of cornstarch. When we directly gelatinize the sago pith waste, the viscosity is so high that we cannot agitate it. Therefore, we tried direct liquefaction, expecting that the 
Table 23.2 Glucose yield treated with micro-powdering, heating, and the addition of Termamyl $120 \mathrm{~L}$

\begin{tabular}{l|l|l}
\hline & With micro-powdering treatment & Without micro-powdering treatment \\
\hline Yield $(\%)$ & 101 & 87 \\
\hline
\end{tabular}

Source: Sakakura (2013)

viscosity would decrease by starch hydrolysis. However, our expectation was not realized because the gelatinization temperature, at approximately $75^{\circ} \mathrm{C}$, was lower than optimal enzyme temperature of approximately $95^{\circ} \mathrm{C}$. Therefore, we combined micro-powdering treatment, direct gelatinization, and direct liquefaction. The micro-powdering treatment of sago pith waste was done using a Super Masscolloider (Masuko Sangyo Co., Ltd., Japan) with tap water. After the treatment, the slurry was heated with Termamyl $120 \mathrm{~L}$ (Novozymes). Table 23.2 demonstrates that the combination of the three treatments makes glucose from the starch in the pith waste.

\subsection{Properties of Metroxylon spp. Sago Palm Starch}

The genus Metroxylon is divided into two sections: Metroxylon and Coelococcus (see Chap. 4). In this chapter, we explain the starch properties of three species of the Coelococcus section: M. vitiense, $M$. warburgii, and M. amicarum.

Scanning electron microscopy images of six sago starches are shown in Fig. 23.4. All starch shapes have a bell or oval form. The results of the starch size distribution show that $M$. sagu and $M$. warburgii are similar in size but that $M$. vitiense and $M$. amicarum are smaller than $M$. sagu (Table 23.3).

The crystalline types of these starches are similar, showing a $\mathrm{C}$ type and approximately $30 \%$ crystallinity (Table 23.3). These data indicate that all samples have similar properties.

The starch contents of four species are shown in Table 23.3. Metroxylon sagu shows the highest starch content, followed by $M$. amicarum and $M$. warburgii; the lowest starch content was found in M. vitiense. The gelatinization properties of these starches are also similar (Table 23.4).

These results demonstrate that the starch properties of palms of the Coelococcus section are similar to those of the Metroxylon section. However, the starch yields of the Coelococcus species are about one-half those in the Metroxylon section; interestingly, the Coelococcus palms reflect a different non-swampy natural habitat. 
Viti Levu, Fiji (M.vitiense)

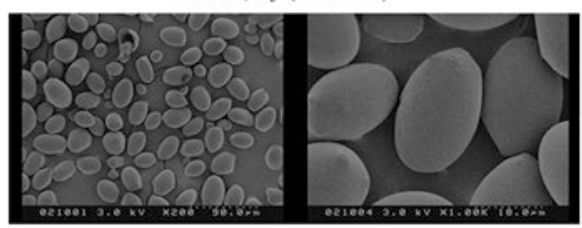

Santo, Vanuatu(M.wagurgii)

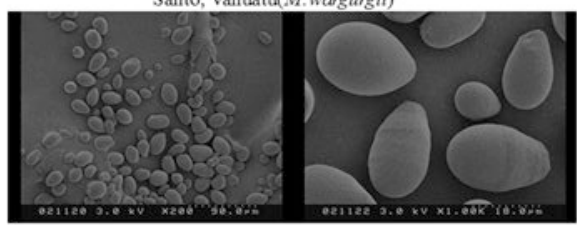

Moen, Micronesia (M.anicarum)

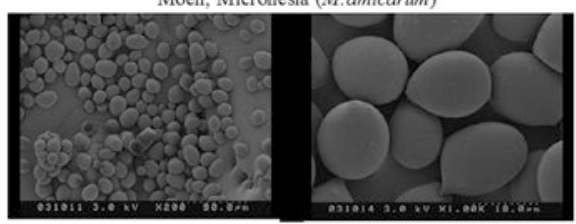

Vanua Levu, Fiji (M.vitiense)

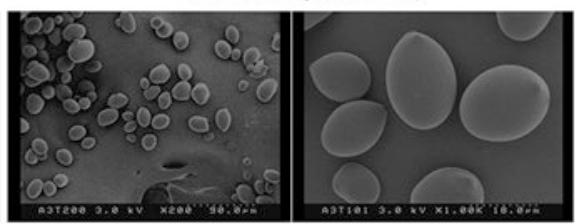

Upolu, Samoa (M.warburgil)

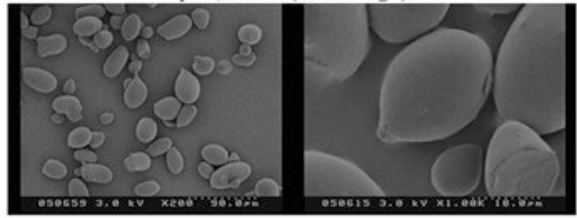

Central Karimantan,Indonesia ( $M . s a g u$ )

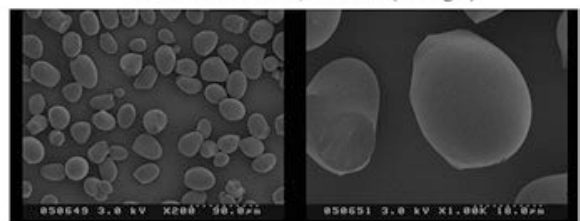

Fig. 23.4 Scanning electron microscopy image of sago starch Acceleration voltage: $3 \mathrm{kV}$. (Source: Mamiya 2005)

Table 23.3 Physicochemical properties of sections of various sago starches

\begin{tabular}{l|l|l|l|l|l}
\hline & $\begin{array}{l}\text { Long diameter } \\
(\mu \mathrm{m})\end{array}$ & $\begin{array}{l}\text { Short diameter } \\
(\mathrm{mm})\end{array}$ & $\begin{array}{l}\text { Crystallinity } \\
(\%)\end{array}$ & $\begin{array}{l}\text { Crystalline } \\
\text { type }\end{array}$ & $\begin{array}{l}\text { Starch } \\
\text { content }(\%)\end{array}$ \\
\hline $\begin{array}{l}\text { Metroxylon } \\
\text { vitiense }\end{array}$ & 21.6 & 15.7 & 29.4 & $\mathrm{C}$ & 27 \\
\hline M. warburgii & 29.2 & 19.3 & 28.7 & $\mathrm{C}$ & 36 \\
\hline M. amicarum & 19.0 & 15.5 & N.T. & $\mathrm{C}$ & 39 \\
\hline M. sagu & 30.5 & 21.8 & 32.3 & $\mathrm{C}$ & 77 \\
\hline
\end{tabular}

Source: Kako (2004)

Table 23.4 DSC properties of various sago starches

\begin{tabular}{l|l|l|l|l}
\hline & $\mathrm{To}\left({ }^{\circ} \mathrm{C}\right)$ & $\mathrm{Tp}\left({ }^{\circ} \mathrm{C}\right)$ & $\mathrm{Tc}\left({ }^{\circ} \mathrm{C}\right)$ & $\Delta \mathrm{H}(\mathrm{mJ} / \mathrm{mg})$ \\
\hline Metroxylon vitiense & 66.1 & 69.5 & 73.8 & 13.7 \\
\hline M. warburgii & 65.4 & 69.2 & 73.7 & 13.7 \\
\hline M. sagu & 66.6 & 71.7 & 76.9 & 15.4 \\
\hline
\end{tabular}

Source: Kako (2004) 


\section{References}

Agriculture \& Livestock Industries Corporation (2004) Sugar trivia. About isomerized glucose syrup http://sugar.alic.go.jp/tisiki/ti_0408.htm [in Japanese]

Agriculture \& Livestock Industries Corporation (2008) The situation regarding tapioca starch in Thailand http://www.alic.go.jp/starch/world/country/200802-03.html [in Japanese]

Ehara H, Naito H, Mizota C (2005) Environmental factors limiting sago production and genetic variation in Metroxylon sagu Rottb. In: Karafir YP, Jong FS, Fere VF (eds) Sago palm development and utilization: proceedings of the 8th international sago symposium. Universitas Negri Papua Press, Manokwari, pp 93-103

Jong FS (1995) Distribution and variation in the starch content of sago palms (Metroxylon sagu Rottb.) at different growth stages. Sago Palm 3(2):45-54

Kako S (2004) Physicochemical properties of starch from Metroxylon section Coelococcus. Master's thesis, Mie University [in Japanese]

Mamiya K (2005) Physicochemical properties and molecular shape of sago starch. Master's thesis, Mie University [in Japanese]

Ministry of Agriculture, Forestry and Fisheries, Japan (2009) The situation regarding potatoes and starch http://www.maff.go.jp/j/study/denpun/h210710/pdf/data3.pdf [in Japanese]

Sakakura K (2013) Study on production of isomerized sugar using sago palm starch extraction residue. Master's thesis, Mie University [in Japanese]

Santoso B, Sakakura K, Naito H et al (2015) Effects of micro powder milling on physicochemical properties of sago starch. J Appl Glycosci 62(2):73-80

Whistler RL (2009) Development of specialty starches. In: BeMiller J, Whistler RL (eds) Starch: chemistry and technology, Third edn. Academic Press, London, pp 6-9

Open Access This chapter is licensed under the terms of the Creative Commons Attribution 4.0 International License (http://creativecommons.org/licenses/by/4.0/), which permits use, sharing, adaptation, distribution and reproduction in any medium or format, as long as you give appropriate credit to the original author(s) and the source, provide a link to the Creative Commons license and indicate if changes were made.

The images or other third party material in this chapter are included in the chapter's Creative Commons license, unless indicated otherwise in a credit line to the material. If material is not included in the chapter's Creative Commons license and your intended use is not permitted by statutory regulation or exceeds the permitted use, you will need to obtain permission directly from the copyright holder. 